\title{
EKSISTENSI BAHASA DAYAK KENYAH DI KOTA \\ BALIKPAPAN KALIMANTAN TIMUR
}

\author{
Rika Istianingrum \\ Universitas Balikpapan Kalimantan Timur \\ (riekaistianingrum@gmail.com)
}

\begin{abstract}
ABSTRAK
Pemertahanan dan pergeseran bahasa merupakan dua gejala kebahasaan yang saling terkait. Bahasa dikatakan mengalami pergeseran ketika suatu masyarakat mulai meninggalkan bahasa daerahnya. Dayak Kenyah merupakan salah satu suku tertua yang mendiami provinsi Kalimantan Timur. Bahasa Dayak Kenyah pada masa sekarang telah mengalami pergeseran bahasa, masyarakatnya pun telah beralih menggunakan bahasa Indonesia. Hal ini juga didukung oleh situasi kota Balikpapan yang merupakan salah satu kota industri di Kalimantan Timur. Serta berpengaruh langsung terhadap gaya hidup masyarakatnya yang multikultural. Penelitian ini bersifat deskriptif kualitatif dan menggunakan metode analisis isi, serta pendekatan sosiolinguistik dengan menerapkan langkah-langkah analisis data, yaitu pereduksian data, penyajian data, dan penarikan kesimpulan. Melalui penelitian ini dapat diketahui sejauhmana masyarakat Dayak Kenyah dalam mempertahankan eksistensi bahasanya di masyarakat multikultural yaitu Kota Balikpapan. Penelitian ini diarahkan pada pengetahuan mengenai usaha yang dilakukan oleh masyarakat Dayak Kenyah dalam mempertahankan bahasanya, mendeskripsikan faktor pemertahanan bahasanya, menjelaskan dampak dan makna pemertahanan bahasa Dayak Kenyah di kota Balikpapan.
\end{abstract}

Kata kunci: eksistensi, pemertahanan bahasa Dayak Kenyah

\section{A. PENDAHULUAN}

Eksistensi merupakan sebuah keberadaan suatu diri. Eksistensi bahasa sangat diperlukan oleh semua bangsa atau daerah untuk menunjukkan keberadaan dirinya. Apakah masih dikatakan bertahan atau telah punah. Di Indonesia terdapat bermacam- macam suku bangsa yang berarti pula terdapat banyak bahasa daerah. 
Menurut data dari Ethnologue (Anashir, 2012) Indonesia merupakan negara yang memiliki banyak bahasa daerah. Indonesia memiliki 726 bahasa yang dituturkan oleh berbagai etnis di seluruh wilayah Indonesia. Dari 726 bahasa daerah di Indonesia, beberapa bahasa daerah tetap dipertahankan keberadaannya dalam berkomunikasi dan berinteraksi. Di antaranya adalah bahasa Jawa, bahasa Sunda, bahasa Bugis, bahasa Banjar, bahasa Aceh, bahasa Betawi, bahasa Madura, bahasa Minangkabau, bahasa Bali, bahasa Musi.

Di antara bahasa-bahasa daerah yang mulai mengalami pergeseran dan sulit Untuk dipertahankan oleh masyarakatnya adalah bahasa Dayak yang terdapat di Kalimantan Timur. Hal ini dikarenakan banyak masyarakat pendatang dari luar Kalimantan yang mendiami pulau tersebut. Maka dari itu, pemertahanan bahasa Dayak harus dioptimalkan. Penelitian ini membahas eksistensi bahasa Dayak Kenyah di Kota Balikpapan Kalimantan Timur.

Pergeseran bahasa menyangkut masalah penggunaan bahasa oleh seorang penutur atau sekelompok penutur yang bisa terjadi sebagai akibat dari suatu masyarakat tutur ke masyarakat tutur lain (Chaer, 2004:142). Jika seorang atau sekelompok orang penutur pindah ke tempat lain yang menggunakan bahasa lain, dan bercampur dengan mereka, maka akan terjadilah pergeseran bahasa tersebut.

Konsep tentang pemertahanan bahasa adalah konsep yang terkait erat dengan perencanaan bahasa (Kaplan, 1991:146). Pemertahanan bahasa adalah salah satu tujuan dari perencanaan bahasa. Pemertahanan bahasa direncanakan oleh perencana-perencana bahasa minoritas untuk menghindari kepunahan bahasa minoritas dalam suatu bangsa. Hal tersebut dilakukan dengan penuh kesadaran sebagai reaksi adanya masalah kebahasaan akibat pemilihan bahasa nasional. Dalam kajian sosiolinguistik, dikenal juga terjadi kebertahanan bahasa minoritas oelh penuturnya. Kebertahanan bahasa minoritas terjadi sevcara tidak sengaja dan tidak direncanakan sebelumnya. Hal ini terkait erat dengan penggunaan bahasa berlatar sosial budaya dan psikologis penuturnya, letak geografis, dan demografis.

Bahasa Dayak Kenyah merupakan salah satu bahasa daerah yang berada di Indonesia. Sebagai bahasa daerah yang eksistensinya masih dipakai dalam berkomunikasi, dihargai, dipelihara oleh masyarakat, dan negara karena bahasa Dayak merupkan bagian dari khazanah dan budaya Indonesia. Bahasa Dayak 
Kenyah merupakan bahasa daerah yang jumlah punuturnya minoritas di tanah Kalimantan Timur khususnya di Kota Balikpapan, yaitu kurang lebih 100 KK (Kepala Keluarga) . Namun, sebagai bahasa minoritas, penutur bahasa dayak Kenyah tetap bangga dan melestarikan serta mempertahankan bahasanya. Selain itu, Suku Dayak Kenyah memiliki keunikan tersendiri dalam cirri fisiknya yaitu adanya tato di setiap badannya dan telinga yang panjang.

Kota Balikpapan merupakan salah satu kota terbesar di Kalimantan Timur yang mayoritas dihuni oleh pendatang dari suku Jawa, suku Madura, suku Bugis, suku Banjar, serta suku Dayak. Suku Dayak menggunakan bahasa Dayak sebagai bahasa ibu. Suku Dayak merupakan etnis minoritas di Kota Balikpapan. Suku Kenyah adalah suku Dayak yang termasuk rumpun Kenyah-Kayan-Bahau yang berasal dari daerah Baram, Sarawak.

Asal usul Suku dayak Kenyah dimulai dari pergerakan suku ini menuju ke hilir akhirnya sampai ke daerah Mahakam dan akhirnya sebagian menetap di Kampung Pampang Samarinda Utara, Samarinda. Sebagian lagi bergerak ke hilir menuju Tanjung Palas. Suku Kenyah merupakan 2,4\% penduduk kota Balikpapan. Silsilah dan Sub Suku Dayak Kenyah Klan besar Dayak Kenyah, konon, berasal dari keturunan para pedagang Cina dan suku Barunai (Brunai Darussalam). Dalam perkembangannya, Klan ini terbagi menjadi 30 subsuku, yang memiliki nama tersendiri dan masing-masing memiliki kepala adat. Dayak Kenyah, yang mendiami pulau Kalimantan/Borneo, khususnya Kalimantan Timur, terdiri dari 22 Sub suku. Setiap sub suku biasanya disebut lepoq/umaq, yaitu: Lepoq Bakung, Uma Jalan, Lebuk Kulit , Lebuk Timai, Lepoq Tukung, Lepoq Bem , Lepoq Ma'ut, Uma Lasan , Uma Lung, Lepoq Tau, , Lepoq Kayan, Lepoq Punan, Lepoq Brusuq, Uma Baka, Uma Alim, Lepoq Entang , Lepoq Kei, Lepoq Puaq, Lepoq Tepu, Lepoq Badeng, Lepoq Merap. Yang membedakan di antara sub suku Dayak Kenyah ini adalah mengenai cara pengucapan akhir kata (setiap sub suku mempunyai ciri khas dialek/logat yang berbeda beda).

Semua suku hidup berdampingan dalam satu pemukiman. Suku Dayak Kenyah bersama suku Dayak lainnya serta suku pendatang menjaga dengan baik hubungan mereka. Pada akhirnya antara suku-suku yang berbeda tersebut terjadi interaksi dalam kehidupan sehari-harinya. Bahasa pengantar suku tersebut bukan 
bahasa Dayak, bahasa Jawa ataupun bahasa Banjar sebagai bahasa lokal, tetapi mereka memilih menggunakan bahasa Indondesia. Pada umumnya suku pendatang menggunakan bahasa ibu atau bahasa asli mereka jika berinteraksi dengan para penutur yang berasal dari daerah yang sama.

Pengaruh global dan masyarakat multikultural tersebut mempengaruhi kesadaran, sikap, dan tindakan sebagian masyarakat Balikpapan terhadap bahasa Kenyah sebagai salah satu identitas budaya. Hal ini sangat tampak dalam fenomena kurangnya penggunaan bahasa Kenyah dalam komunikasi masyarakaat Dayak yang berada di Kota Balikpapan. Masyarakat Kenyah cenderung mengikuti gaya hidup impor sebagai akibat dari Kota Balikpapan merupakan pusat pariwisata dan kota industrialisasi yang hampir sebagian besar menggunakan bahasa Indonesia dan bahasa Asing daripada menggunakan bahasa daerah. Hal ini tampak pada dalam lingkup pergaulan masyarakat multikultural di Kota Balikpapan, bahkan terkadang menggunakan bahasa campuran anatara bahasa Kenyah, bahasa Indonesia, dan bahasa asing, daripada menggunakan bahasa Dayak yang utuh. Kemauan anak-anak dalam menggunakan bahasa daerahnya dirasa pun kurang, bahkan dalam kehidupan keluarga, orang tua jarang mengarahkan anaknya menggunakan bahasa Kenyah. Namun ada beberapa keluarga yang tetap menggunakan serta mengajarkan bahasa Kenyah meskipun dalam penggunaannya masih bercampur dengan bahasa Indonesia.

Bertolak dari uraian di atas walaupun bahasa kenyah merupakan ciri penting untuk menentukan identitas keetnikan suatu kelompok, nampaknya bahasa kenyah tidak selalu dapat dipertahankan namun bukan berarti bahasa kenyah harus ditinggalkan begitu saja. Bahasa Kenyah justru harus didayagunakan agar budaya yang adi luhung tidak tercerabut dari akarnya. Dalam menghadapi guncangan perubahan sosial yang begittu cepat dan kuat, pemertahanan bahasa Kenyah dalam masyarakat multikultural di Kota Balikpapan merupakan upaya yang relevan untuk mempertahankan bahasa Kenyah sebagai salah satu warisan leluhur sejak dahulu kala.

Penelitian ini memfokuskan pada eksistensi keberadaan serta pemertahanan bahasa Dayak Kenyah di Kota Balikpapan. Penelitian ini diarahkan pada pengetahuan mengenai usaha yang dilakukan oleh masyarakat Dayak Kenyah 
dalam mempertahankan bahasanya, mendeskripsikan faktor pemertahanan bahasanya, menjelaskan dampak dan makna pemertahanan bahasa Dayak Kenyah di kota Balikpapan. Sebab dilihat dari segi populasi masyarakat Dayak Kenyah di Kota Balikpapan tidak terlalu banyak jumlah jiwanya (100 KK) tapi mampu eksis di atas suku pendatang lain yang populasinya lebih mendominasi. Selain itu, penelitian terhadap bahasa dayak Kenyah di Kota Balikpapan Kalimantan Timur belum pernah dilakukan oleh peneliti lainnya. Hal ini juga memotivasi peneliti dalam upaya mendokumentasikan bahasa Dayak Kenyah sebagai salah satu bahasa yang di gunakan di Kota Balikpapan selain bahasa Jawa, bahasa Madura, bahasa Bugis, dan bahasa Banjar.

\section{METODE}

Penelitian ini bersifat deskriptif kualitatif dan menggunakan metode analisis isi, serta pendekatan sosiolinguistik. Adapun teknik pengumpulan datanya berupa teknik observasi, wawancara, serta studi dokumen. Kemudian teknik analisis datanya dilakukan dalam beberapa proses yaitu dengan menerapkan langkah-langkah analisis data berupa pereduksian data, penyajian data, dan penarikan kesimpulan.

\section{B. HASIL DAN PEMBAHASAN}

1. Upaya Pemertahanan Bahasa Dayak Kenyah di Kota Balikpapan

Pemertahanan bahasa lebih mengacu kepada sebuah situasi di mana anggota-anggota sebuah komunitas bahasa mencoba untuk menjaga bahasa yang mereka miliki dengan cara menggunakannya. Karena bahasa memang selalu berubah, maka yang diharapkan adalah perubahan yang positif dan stabil. Artinya, bahasa tersebut tetap dipergunakan oleh masyarakat penuturnya dan diturunkan pada generasi berikutnya secara berkelanjutan. Inilah konsep dari pemertahanan. Dalam pengertian ini, bahasa bertahan secara dinamis walaupun mengalami pergeseran dan perubahan dari generasi ke generasi. Oleh karena itu, pentingnya adanya upaya-upaya pemertahanan bahasa pada suku daerah di Indonesia.

Upaya-upaya pemertahanan bahasa Dayak Kenyah pada bagian ini dipahami sebagai cara, tindakan, atau pun sikap yang dapat menunjang penggunaan bahasa Dayak Kenyah serta kebertahanannya dari berbagai pengaruh 
perubahan sosial yang ada dalam hidup bermasyarakat. Upaya-upaya pemertahanan bahasa Dayak Kenyah dalam masyarakat di Kota Balikpapan dapat diuraikan sebagai berikut.

\section{Upaya Pemertahan Bahasa Dayak Kenyah dalam Keluarga}

Upaya pemertahanan bahasa Dayak kenyah tidak terlepas dari parole dalam kegiatan sehari-hari masyarakat Dayak. Bahasa secara umum berfunsi sebagai alat komunikasi dalam interaksi masyarakat. Bahasa Dayak Kenyah digunakan sebagai bahasa pengantar di dalam interaksi masyarakat maupun sebagai alat komunikasi dalam keluarga.

Keluarga, dalam kaitannya dengan konteks di atas, dipahami sebagai wadah bagi anggotanya untuk berkomunikasi, karena keluarga merupakan tempat pertama bagi seseorang untuk belajar tentang sesuatu hal. Dengan komunikasi anggota keluarga dapat saling memahami antara orang tua dengan anaknya atau sebaliknya antara anak dengan orang tua, juga di antara anggota lainnya.

Situasi demikian tampak dalam suasana keluarga Bapak Jimi (Kepala Lembaga Adat Dayak kenyah Balikpapan) Berikut tuturan komunikasi yang dilakukan oleh Bapak Jimi dengan istrinya yang direkam pada tanggal 13 Mei 2015, dalam situasi santai dengan menggunakan bahasa Dayak Kenyah sebagai berikut.

Bapak Jimi : "We, uyan kupi ca, ngan the deng leto ni."

Ibu Jimi : "Ahaq amai, nena nisep the ni leto. Silahkan Mbak."

Percakapan di atas diterjemahkan dalam bahasa Indonesia sebagai berikut.

Bapak Jimi : "Ibu, tolong buatkan kopi satu, dan untuk mbak ini teh."

Ibu Jimi : "Iya Pak. Untuk Bapak kopi susu ya. Untuk mbak ini tehnya. Silahkan Mbak.”

Berikut pula juga dihadirkan sebuah tuturan santai antara Ibu Agustina dengan putranya yang bernama James, ketika sedang ada tamu yang berkunjung di rumahnya di jalan Sempaja Villa Ana (tanggal 9 Mei 2015).

Ibu Agustina : "Jim, tolong ko pedae penguman deng sakai dini adding." 
James : "Ahaq, We. Idi ca lekai kare ayam deng meja ende. Uman nah."

Ibu Agustina : "Tiga tawai nah, Jim. (sambil tersenyum pada James). Anak saya, James ini, meskipun anak lelaki tetapi mau membantu ibunya menyiapkan makanan untuk keluarga, Nak."

Arti dialog tersebut dalam bahasa Indonesia adalah sebagai berikut.

$$
\begin{array}{ll}
\text { Ibu Agustina } & : \text { "Jim, tolong siapkan makanan untuk tamu ini." } \\
\text { James } & : \text { "Sudah, buk. Ini ada sayur kare ayam di meja makan. } \\
& \text { Silahkan." } \\
\text { Ibu Agustina : } & \text { "Terima kasih, Jim (sambil tersenyum pada James). Anak } \\
& \text { saya, James ini, meskipun anak lelaki tetapi mau } \\
& \text { membantu ibunya menyiapkan makanan untuk keluarga, } \\
& \text { Nak." }
\end{array}
$$

Dialog tuturan di atas tampak adanya hubungan yang akrab dan kasih sayang antara ibu dan anak dalam keluarga. Hubungan kasih sayang tampak dalam meminta tolong sang ibu kepada anak lelakinya untuk menyiapkan makanan. Padahal kita ketahui di dalam masyarakat umumnya, bahawa menyiapkan makanan adalah tugas dari seorang perempuan. Namun, dalam keluarga Ibu Agustina yang tidak mempunyai anak perempuan, anak lelaki pun sama saja, tetap dididik untuk saling menolong meskipun itu berkaitan dengan pekerjaan perempuan. Konteks dialog keluarga pada tuturan di atas menunjukkan bahwa bahasa Dayak Kenyah merupakan alat komunikasi yang dapat digunakan dalam kehidupan sehari-hari. Keluarga merupakan salah satu kekuatan dalam upaya pemertahanan bahasa Dayak Kenyah dalam masyarakat multikultural di Kota Balikpapan.

\section{Upaya Pemertahanan Bahasa Dayak Kenyah di Pasar Tradisional}

Penutur bahasa Dayak Kenyah di Kota Balikpapan sangat minoritas. Hal ini juga berdampak pada komunikasi dan interaksi dengan masyarakat Balikpapan 
yang mayoritas pendatang dari suku Jawa. Ketika dalam situasi tertentu di pasar tradisional pun, tuturan yang dipakai menggunakan bahasa Indonesia. Namun dengan logat kedaerahan. Begitu pula penutur dari Dayak Kenyah, ketika berada dalam masyarakat pasar, serta berinteraksi dengan penutur lainnya, menggunakan bahasa Indonesia logat Dayak. Fenomena tersebut sangat mempengaruhi upaya pemertahanan bahasa Dayak Kenyah di Kota Balikpapan dalam situasi masyarakat pasar.

Tetapi ketika di daerah Pampang Samarinda, yaitu kampung Dayak Kenyah, masyarakat Kenyah menggunakan tuturan bahasa Dayak Kenyah untuk komunikasi dan interaksi mereka. Daerah Pampang Samarinda hanya berjarak 3 jam dari Balikpapan. Samarinda adalah ibukota provinsi Kalimantan Timur. Samarinda dan Balikpapan merupakan kota yang multikultural di Kalimantan Timur. Seperti tuturan di bawah ini, seorang penutur dari Dayak menawar barang dagangan dari seorang Nenek yang berasal dari Kampung Kenyah (tanggal 9 Mei 2015).

Ibu Agustina : "Pui, uleng ni kudaq beli?"

Nenek : "Beli req 200 libu, iyaq umit 80 libu. Nena mileq ne pengubaq kem."

Ibu agustina : "Iyaq lataq ni re 80 libu ko, Pui?"

Nenek : "Empi encam lepa we. 150 ina."

Ibu Agustina : "Ahaq pa, Pui. Akeq meli nah 150 libu. Tiga tawai na, Pui."

Arti dialog tersebut dalam bahasa Indonesia adalah sebagai berikut.

Ibu Agustina : "Nenek, kalung ini harganya berapa?"

Nenek : : "Itu harganya 200 ribu. Yang kecil 80 ribu. Ayo, silahkan dipilih."

Ibu agustina : "Yang besar ini boleh ya 80 ribu, Nenek."

Nenek : :Belum bisa, Bu. 150 ya, silahkan."

Ibu agustina : "Ya sudah Nenek, saya beli 150 ribu. Terima kasih, Nenek." 
Melihat konteks tuturan di atas bahwa kegiatan transaksi jula beli barang memakai bahas Dayak Kenyah hanya terdapat pada pasar tradisional yang ada di kampung Pampang Kenyah. Ketika berada di luar kampung tersebut, masyarakat memakai tuturan bahasa Indonesia, karena tidak banyak masyarakat pendatang yang paham dengan bahasa Dayak Kenyah. Dengan demikian konsep pemertahanan bahasa Dayak Kenyah di lingkungan pasar tradisional kurang diupayakan, hanya pasar-pasar tertentu saja yang penuturnya banyak dari Kenyah yang mempertahankan bahasa tersebut.

\section{Upaya Pemertahanan Bahasa Dayak Kenyah dalam Kegiatan Keagamaan}

Kegiatan keagamaan merupakan kegiatan yang tidak terpisahkan dari kehidupan masyarakat. Keagaaman secara sosiologis dilihat sebagai salah satu unsur pembentuk masyarakat. Hal itu berarti, kegiatan keagamaan tidak hanya sebagai salah satu unsur pembentuk masyarakat tetapi juga ciri khas hidup bermasyarakat itu sendiri.

Bahasa Dayak Kenyah selain sebagai bahasa komunikasi dalam masyarakat sesama penutur bahasa Kenyah, juga merupakan pengantar dalam berbagai kegiatan keagamaan. Kegiatan keagamaan masyarakat Dayak Kenyah banyak dijumpai di gereja dalam acara kebaktian atau hal lain. Namun, pemakaian bahasa Kenyah tidak sering digunakan. Hal ini, merujuk pada tidak hanya masyarakat Kenyah yang mengikuti kegiatan keagaamaan di geraja, tapi juga masyarakat pendatang lain seperti suku Bugis, suku Jawa yang beragama Kristen.

Melihat fenomena di masyarakat tersebut, telah diketahui bahawa dalam bidang keagamaan, upaya pemertahanan bahasa Dayak kenyah di Kota Balikpapan masih minim pelestariannya, karena mengingat di Kota Balikpapan terdapat banyak suku lain yang mendiaminya.

\section{Upaya Pemertahanan Bahasa Dayak Kenyah dalam Kegiatan Adat}

Adat adalah suatu kegiatan, perbuatan yang lazim dilakukan sejak dahulu kala, cara kelakuan yang sudah menjadi kebiasanaan. Hidup sebagai masyarakat, tidak terlepas dari adat dan kebiasaan yang sudah lazim dipraktikkan dalam kehidupan sehari-hari. Masyarakat Kenyah yang ada di Kota Balikpapan sering 
berkumpul dan membahas segala sesuatu yang berkaitan dengan adat. Meskipun berbeda dengan upacara adat di Desa Pampang Samarinda, masyarakat Kenyah yang terdapat di Kota Balikpapan mempunyai sebuah paguyuban adat, yang bernama Lembaga Adat Dayak Kenyah, dengan kepala adat yang bernama Bapak Jimi (polres Balikpapan). Dalam rapat paguyuban, masyarakat Kenyah sering menggunakan bahasa daerahnya ketimbang bahasa Indonesia. Seperti yang dikatakan oleh Bapak Jimi dalam wawancara tanggal 11 Mei 2015.

"Shalom, Bangen ne lo pempau ngadan Tuhan Yang Maha Esa, moq uben peniga Tuhan, deng ilu lo nai kelu'ung kaq amin ini. Palak undangan iyaq akeq selum, seq nai tepat petegoq liwai ini re dau lo ke tirak kumpin seq ilu ke uyan dalem puyan ini, pa'an ina lak kaduq lepa iyaq ilu ke pisiu ban dau asset-aset paguyuban ngan toq seq uleq gayeng lepek ne tei dalamkas paguyuban, ngan lo ke pisiu kumpin seq puyan lo o'o ini deng 6 bulan iyaq kenai."

Artinya dalam bahasa Indonesia adalah sebagai berikut.

"Salam, rasa syukur saya panjatkan kehadapan tuhan Yang Maha Esa, karena berkat rahmat Tuhan, kita dapat berkumpul pada kesempatan yang baik ini. Para undangan yang saya hormati, pertemuan ini tiada lainmembahas tentang pelaksanaan acara kebudayaan yang sudah dilaksanakan, selain tersebut juga membahas tentang asset-aset paguyuban serta hasil yang didapat yang sudah masuk ke kas paguyuban, juga membahas program yang perlu dipersiapkan untuk enam bulan ke depan.”

Kutipan di atas dilakukan oleh Bapak Jimi selaku kepala Lembaga Adat Dayak Kenyah ketika sedang memulai rapat paguyuban Kenyah. Bapak Jimi dalam pengantar atau ceramahnya menggunakan bahasa Kenyah. Karena dalam lembaga paguyuban tersebut yang hadir mayoritas penutur Kenyah, meskipun ada penutur dari suku lain, namun tuturan bahasa kenyah tetap digunakan.

Ungkapan informan tersebut menunjukkan bahwa betapa pentingnya peran bahasa Dayak Kenyah sebagai sarana komunikasi yang tepat dalam berbagai kegiatan adat yang ada dalam masyarakat Kenyah di Kota Balikpapan. Dengan 
demikian, kegiatan adat merupakan kekuatan dalam upaya pemertahanan bahasa Dayak Kenyah dalam masyarakat multikultural di kota Balikapan.

6. Upaya Pemertahanan Bahasa Dayak Kenyah dalam Pementasan Kesenian

Kegiatan kesenian tradisional merupakan kegiatan hiburan yang dilatari oleh budaya lokal Dayak. Kesenian juga merupakan sarana pelestarian bahasa Kenyah. Kesenian tradisional dalam hal ini dilihat sebagai sarana untuk pemertahanan sekaligus pengembangan bahasa Kenyah. Upaya pemertahanan bahas Kenyah dalam pementasan kesenian di Balikpapan hanya sebatas jika ada kegiatan-kegiatan tertentu yang berhubungan dengan acara kebudayaan. Biasanya masyarakat Kenyah menampilkan tarian-tarian Kenyah yang didasari oleh kehidupan Dayak Kenyah masa lampau.

Namun, ketika di Desa Pampang Samarinda, upaya pemertahanan bahasa Kenyah melalui kesenian telah terlihat. Hal ini karena masyarakat setempat sering mementaskan tarian adat mereka di Lamin, sebuah rumah panjang khas Dayak Kenyah. Tarian0tarian adat Kenyah dipentaskan di dalam Lamin dihadapan para pengunjung yang menyaksikan pementasan tersebut. Acara pementasan tersebut diadakan setiap hari Minggu pukul 14.00 waktu setempat. Pada awalnya pendeta yangbertugas untuk membuka acara kesenian menggunakan bahasa Kenyah namun selanjutnya menggunakan bahas Indonesia. Karena pengunjung acara tersebut mayoritas dari suku pendatang. Seperti kutipan di bawah ini.

"Shalom, Bangen ne lo pempau ngadan Tuhan Yang Maha Esa, moq uben peniga Tuhan, deng ilu lo nai kelu'ung kaq amin ini di tanah Lamin. Hari ini kita saksikan pementasan kesenian dari Dayak Kenyah yang akan dipentaskan oleh para penari-penari dari masyarakat Pampang."

Dalam konteks tersebut jelas bahawa meskipun kegiatan kesenian masyarakat Kenyah, beberapa bahasa pengantarnya menggunakan bahasa Indonesia. Hal ini karena banyak suku pendatang yang menyaksikan pementasan kesenian adattersebut. Namun begitu, nama-nama tarian yang dipentaskan tetap menggunakan bahasa Kenyah, di antaranya tarian Kancet Papatai (tarian Perang), Tarian Kancet Ledo (tarian Gong), Tari Pacuk Kina, Tari Kancet Lasan, Tari 
Datun, Tari Lelleng. Berkaitan dengan uraian tersebut, tampak bahwa pementasan kesenian merupakan kekuatan dalam upaya pemertahanan bahasa Kenyah di masyarakat multikultural Kota Balikpapan.

\section{Faktor-faktor Pemertahanan Bahasa Dayak Kenyah di Kota Balikpapan}

Bertahan atau bergesernya sebuah bahasa, baik pada kelompok minoritas maupun pada kelompok imigran transmigran dapat disebabkan oleh banyak faktor. Hasil-hasil penelitian terdahulu menunjukkan bahwa faktor industrialisasi dan urbanisani/transmigrasi merupakan faktor utama. Selain itu, faktor konsentrasi wilayah pemukiman merupakan faktor penting dibandingkan dengan jumlah penduduk yang besar. Kelompok yang kecil jumlahnya pun dapat lebih giat mempertahankan bahasanya, jika kosentrasi wilayah pemukiman dapat dipertahankan, sehingga terdapat keterpisahan secara fisik, ekonomi, dan sosial budaya.

a. Faktor Prestise

Suku Kenyah sangat bangga dengan budayanya termasuk dengan bahasa yang mereka gunakan. Artinya, nilai prestise seseorang yang menggunakan bahasa Kenyah di tengah bahasa multikultural lebih tinggi. Namun, pada kondisikondisi tertentu, penutur Kenyah dirasa sangat kurang dan tidak mau menggunakan bahasanya. Hal ini jika berkaitan dengan ketika penutur Kenyah berinteraksi dengan suku lain, atau berada di dalam tengah-tengah suku lain. Meskipun penutur dan sang mitra tutur sama-sama berasal dari satu suku yaitu Kenyah. Hal tersebut dilakukan karena untuk menghormati suku lain. oleh karena itu mereka para penutur Kenyah tetap menggunakan bahasa Indonesia.

Dan yang kedua adalah, karena penutur Kenyah sudah lama meninggalkan kampung mereka dan tinggal di kota besar seperti kota Balikpapan yang mayoritas dihuni oleh suku pendatang daripada suku Dayak sendiri. Hal ini pula diikuti pada ranah pendidikan. Di sekolah-sekolah, misalnya anak-anak Kenyah menggunakan bahasa Indonesia sebagai komunikasi pertemanan dengan anak beretnis Jawa, Madura, bugis, Banjar, dll. Fenomena ini sudah menjadi kekahwatiran dari para tetua Kenyah kalau suatu saat anak-anak Dayak tidak bisa lagiberbahasa Dayak. Karena selain di ranah keluarga yang hanya diajarkan bahasa Kenyah. Di sekolah 
mereka berbahasa Indonesia. Oleh karena itu, sikap prestise terhadap bahasa mereka tidak dipertahankan.

b. Faktor Migrasi dan Kosentrasi Wilayah

Migrasi sebenarnya merupakan salah satu faktor yang membawa kepada sebuah pergeseran bahasa. Adanya sejumlah orang dari sebuah penutur bahasa bermigrasi ke suatu daerah dan jumlahnya dari masa ke masa bertambah sehingga melebihi jumlah populsai penduduk asli daerah itu, maka di daerah itu akan tercipta sebuah lingkungan yang cocok untuk pergeseran bahasa.

Di Kalimantan Timur terutama di Kota Balikappan, jumlah populasi suku Jawa lebih besar daripada penduduk asli yaitu Dayak. Bahasa sehari-hari didominasi bahasa jawa dan bahasa Indonesia. Bahasa komunikasi sehari-hari di daerah tersebut hampir tidak kedengaran lagi masyarakatnya berbahasa Dayak.

\section{c. Faktor Publikasi Media Massa}

Media massa juga merupakan faktor lain yang turut menyumbang pemertahanan bahasa Kenyahdi Kota Balikpapan. Namun, upaya pemertahanan dalam lingkup publikasi media massa masih dirasa kurang, karena tidak tampak pada kalimat-kalimat di media massa. Dengan demikian, pemerintah mestinya memperhatikan fenomena seperti ini.

Tetapi dalam media elektronik yaitu televisi, bahasa Dayak Kenyah sering diperkenalkan dalam acara Lintas Kebudayaan yang diputar di TVRI dan stasiun televisi di Balikpapan (BKV). Dalam acara Lintas Kebudayaan, kesenian adat Kenyah dilestarikan.

8. Dampak dan Makna Pemertahanan Bahasa Dayak Kenyah di Kota Balikpapan

Dampak pemertahanan bahasa Kenyah dalam masyarakat multikultural di Kota Balikpapan dalam hal ini dipahami sebagai hal ikhwal yang merupakan akibat dari hal tersebut. Seperti dampak marginalisasi bahasa Kenyah, dualisme masyarakat, dan dampak kekurangmahiran berbahasa Kenyah. 
a. Marginalisasi Bahasa Kenyah

Sikap dan tanggapan masyarakat multikultural di Kota Balikpapan terhadap bahasa Kenyah berdampak terhadap perkembangan bahasa Kenyah. Hal ini berarti bahwa jika masyarakat bersikap positif dan mendukung keberadaan bahasa Kenyah, maka dapat memupuk perkembangan sastra dan bahasa Kenyah. Demikian pula sebaliknaya, jika masyarakat pemakai bahasa bersikap negatif atau kurang mendukung terhadap keberadaan bahasa Kenyah dengan berbagai alasan di dalamnya, maka keberadaan bahasa daerah akan larut dan hilang tanpa makna.

Sikap dan tanggapan masyarakat multikultural di kota Balikpapan terhadap bahasa Kenyah mengenai pemertahanan bahasa kenyah di Kota Balikpapan tersebut menunjukkan sebuah realita marginalisasi bahasa Kenyah di tengah masyarakat multkultutal Kota Balikpapan Kalimantan Timur yang mana mpenduduk Dayak adalah penduduk aslinya. Padahal, fenomena bahasa Kenyah dangat menarik untuk diungkapkan dalam sebuah kajian yang lebih spesifik yang dapat memberikan arah dan penonjolan terhadap aspek-asprek yang sering diangkat dalam tradisi.

b. Dualisme dalam Masyarakat

Pemertahanan bahasa Kenyah dalam masyarakat Kota Balikpapan di tengah kemajuan berbagai bidang kehidupan seperti sekarang ini, bukanlah hal yang mudah. Berbicara mengenai pemertahanan bahasa Kenyah, sering berhadapan dengan suatu dualism yang tidak pernah tampak titik penyelesaiannya dalam masyarakat Balikpapan. Pada satu sisi, ada masyarakat yang bangga dengan menggunakan bahasa Kenyah sebagai harta kekayaan yang tak terhingga nilainya. Karena itu pantas diperjuangkan keberadaannya.

Pada sisi lain, ada segelintir orang yang mengaganggap bahwa bahasa Dayak Kenyah adalah bahasa masyarakat kuno atau primitif, tidak sesuai dengan perkembangan jaman, karena itu ditinggalkan. Orang lebih berorientasi menguasai bahasa Indonesia dan bahasa asing yang dirasa auh lebih modern dan sesuai dengan perkembangan dan perubahan sosial yang ada dalam masyarakat.

Adanya dua sisi mengenai upaya pemertahan bahasa Kenyah mengakibatkan dualisme dalam masyarakat yaitu perbedaan cara pandang antara 
masyarakat yang mempertahankan tradisi dalam hal ini berbahasa Kenyah dengan masyarakat yang mengikuti perkembangan jaman. Dualisme masyarakat terhadap bahasa Kenyah dalam era modern tidak terlepas dari dasar pikiran, pendapat, tindakan, perbuatan, serta pengalaman masyarakau itu sendiri dalam kehidupan sehari-hari.

\section{c. Kekurangmahiran Berbahasa Kenyah}

Penggunaan bahasa Kenyah hanya sebagau pemenuhan tuntutan pariwisata dan yidak mengakar dalam nilai-nilai kehidupan masyarakat multicultural Kota Balikpapan. Misalnya kesakralan bahasa dayak Kenyah sebagai bahasa agama, bahasa kesenian, bahasa adat semakin pudar. Kekurangmahiran berbahasa Kenyah mengakibatkan adanya pertentangan antara penggunaan bahasa kenyah dalam masyarakat Balikpapan, yakni penggunaan bahasa Kenyah yang tidak sesuai dengan nilai-nilai religius dan beralih makna dari religius menjadi sekuler.

\section{d. Makna Pemertahanan Bahasa Dayak Kenyah}

Makna pemertahanan bahasa Kenyah adalah sebagai penguatan solidaritas, pembentuk sikap dan perilaku hidup bermasyarakat, pelestarian bahasa Kenyah sebagai bahasa Ibu, penyadaran identitas etnik. Sebagai penguatan solidaritas, ada pepatah lama yang mengungkapkan bahwa bahasa menunjukkan bangsa. Berdasarkan bunyi pepatah tersebut, dapat diasumsikan bahwa bahasa merupakan aspek penting dalam hubungannya dengan masyarakat. Lebih dari itu, bahasa dapat membentuk dan menentukan keberadaan suatu masyarakat.

Bertitik tolak pada pandangan tersebut, bahasa Kenyah dapat dilihat sebagai salah satu unsur pembentuk masyaraat Balikpapan. Hal ini berarti bahwa jika seseorang menggunakan bahasa Kenyah, orang lain dapat mengetahui bahwa orang tersebut adalah orang Dayak.

Bahasa Kenyah dalam hubungannya dengan masyarakat multikultural di Kota Balikpapan, juga memiliki makna sebagai dalah satu unsur pembentuk masyarakat. Kendatipun masyakat kota Balikpapan berasal dari para pendatang dan suku Jawa yang mendominasi kota tersebut. Kondisi demikian masyarakat 
Kenyah tetap memiliki tempat serta berusaha untuk menunjukkan eksistensinya sebagai mayarakat Balikpapan Kalimantan Timur.

Sebagai pembentuk sikap dan perilaku hidup bermasyarakat, pemertahann bahasa Kenyah dalam masyarakat multikulturak Koda Balikpapan memiliki maksa sebagai pembentuk sikap dan berperilaku hidup bagi masyarakat pemakainya. Misalnya, dalam berbagai upaya pemertajanan bahasa Kenyah secara tidak kangsung masyarakat berupaya mempertahankan nilai-nilai budaya dan warisan leluhur yang terkandung dalam bahasa Kenyah.

Kemudian dengan menyadarkan masyarakat multikultural di kota Balikpapan tentang nilai dan nilai kultural yang terinimplisit dalam bahasa Kenyah dan dapat membanggakan masyarakat dalam menggunakan bahasa Kenyah dalam kehidupan sehari-hari. Dengan demikian, anak-anak dalam keluarga serta enerasi muda sekarang termotivasi untuk mempelajari dan menggunakan bahasa Kenyah dalam lingkup pergaulannya, terutama yang dari suku Dayak Kenyah.

Pemertahanan bahasa Kenyah juga bermakna untuk menegaskan keberadaan pelestarian bahasa kneyah sebagai bahasa Ibu. Masyarakat multikultural di Kota Balikpapan faktanya memiliki beragam bahasa daerah sesuai dengan latar belakang daerah asalnya. Masyarakat kenyah yang hidup dalam masyarakat Kota Balikpapan, selain menggunakan bahasa Indonesia, juga tetap menggunakan bahasa Kenyah dalam waktu tertenu. Misalnya, orang Jawa menggunakan bahasa Jawa dengan warga yang berasal dari Jawa, secara tidak langsung menyadarkan masyarakat Kenyah berbicara dengan menggunakan bahasa Kenyah dengan warga Kenyah.

Situasi keberagaman seperti uraian di atas memberikan makna tersendiri dalam pemertahanan bahsa Kenyah dalam masyaraat Balikpapan. Dengan demikian, jelas bahwa keberagaman bahasa dalam masyarakat multikultural di kota Balikpapan turut memaknai pelestarian bahasa Kenyah sebagai bahasa Ibu.

Sebagai penyadaran identitas etnik. Bahas Kenyah dengan masyarakat penutur bahasa lain di Kota Balikpapan tidak dapat dipisahkan atau saling berhubungan. Bahasa Kenyah merupakan salah satu unsur identitas masyarakat Dayak di kota Balikpapan. 


\section{SIMPULAN}

Berdasarkan hasil pembahasan di atas, penelitian mengenai eksistensi bahasa Dayak Kenyah di Kota Balikpapan ini dapat disimpulkan sebagai berikut. 1 . Upaya-upaya pemertahanan bahasa dayak kenyah di Kota Balikpapan, meliputi 1) upaya pemertahanan di dalam keluarga, 2) upaya pemertahanan di pasar tradisional, 3) upaya pemertahanan di dalam kegiatan keagamaan, 4) upaya pemertahanan di dalam kegiatan adat, 5) upaya pemertahanan di dalam pementasan kesenian. 2. Faktor-faktor pemertahanan bahasa Dayak Kenyah, meliputi 1) faktor prestise, 2) faktor migrasi dan konsentrasi wilayah, 3) faktor publikasi media massa. 3. Dampak dan makna pemertahan bahasa Dayak Kenyah di Kota Balikpapan, meliputi 1) marginalisasi bahasa Dayak Kenyah, 2) dualisme masyarakat, 3) kekurangmahiran berbahasa Dayak Kenyah, 4) makna pemertahanan bahasa Kenyah, di antaranya adalah penguatan solidaritas, pembentuk sikap dan perilaku hidup bermasyarakat, pelestarian bahasa Kenyah sebagai bahasa Ibu, penyadaran identitas etnik.

\section{DAFTAR PUSTAKA}

Chaer, Abdul dan Leonie Agustina. 2004. Sosiolinguistik Perkenalan Awal. Jakarta: Rineka Cipta.

Fasold, Ralph. 1984. The Sociolinguistics of Society. Oxford: Basil Blackwell.

Fishman, Joshua A. 1972. Sociolinguistics a Brief Introduction. Third printing. Massachusetts: Newbury House Publisher.

Kaplan, R.B. 1991. Applied Linguistic and Language Policy and Planning. In Grabe. W\&Kaplan, R.B. (eds) Introduction to Applied Linguistics. 143165. Sydney: Addison Wesley.

Mahsun. 2005. Metode Penelitian Bahasa. Jakarta: PT Raja Grafindo Persada.

Sumarsono. 1993. Pemertahanan Bahasa Loloan di Bali. Jakarta: Pusat Pembinaan dan Pengembangan Bahasa.

Sumarsono. 2011. Sosiolinguistik. Yogyakarta: Pustaka Pelajar. 